J. Fange Manage.

48:402-405 September 1995

\title{
Effect of competition by cheatgrass on shoot growth of Idaho fescue
}

\author{
MOHAMED NASRI AND PAUL S. DOESCHER
}

Authors are former graduate research assistant and associate professor at Oregon State University, Corvallis 97331 2218.

\section{Abstract}

Ability to compete with alien weeds may be one factor enabling high-seral, native bunchgrasses to persist on degraded rangelands. This study examined the effect of competition from cheatgrass (Bromus tectorum L.) on shoot growth of Idaho fescue (Festuca idahoersis. Elmer). Four Idaho fescue collections were cbtained from degraded rangelands, while the fifth was from a site in high ecological condition. Plants were established in pots in a greenhouse with 2 watering regimes, and ratios of Idaho fescue:cheatgrass of 1:0, 1:5, and 1:10. Plants were grown for 56 days. Increasing competition from cheatgrass depleted soil moisture and reduced growth of Idaho fescue. However, Idaho fescue produced greater tiller and leaf numbers than cheatgrass. Idaho fescue plants from the pristine population produced $0.57 \mathrm{~g}$ aboreground biomass while plants from the degraded sites produced $0.31 \mathrm{~g}$. Aboveground biomass from the pristine population was reduced $35 \%$ and $56 \%$ at the $1: 5$ and 1:10 competition levels respectively, compared to the control (1:0 ratio). Aboveground biomass of plants from the degraded populations was similar to the control at the 1:5 level, and was reduced $32 \%$ at the 1:10 level. These results indicated that Idaho fescue from the degraded sites exhibits a different response to competition from cheatgrass than Idaho fescue from the pristine site. This information may prove useful in selecting ecotypes of Idaho fescue for range revegetation.

Key Words: Competition, Festuca idahoensis, Bromus tectorum, ecctype, herbivory

Over the past 150 years, sagebrush steppe communities of the Pacific Northwest have been altered and now include areas dominated by alien annual weeds such as cheatgrass (Bromus tectorum L.). As a result, there has been an overall decline in desirable forage and aesthetic appeal on these lands (Evans and Young 1970,

The authors thank Drs. Doug Johnson, Dale Moss, and Marshall Haferkamp. and 2 anonymous reviewers for helpful reviews of earlier versions. Jay Goodwin aided in the research design. Dr. Dave Thomas, Department of Statisties, Oregon State University, offered statistical advice. This material is based upon work suppored by the Cooperative State Research service, U. S. Department of Agriculture under Agreament No. 88-38300-3623.

Submitted as Technical Paper 10206, Oregon Agricultural Experiment Station,

Oregon State Univ arsity, Corvallis, OR 97331.

Reprint requests to Paul Doescher.

Manuscript accepted 3 Dec. 1994.
Mack 1981, Jordan et al. 1987). Interest is growing to restore rangelands to former native communities (Jordan et al. 1987, Sheridon 1981). There is a constant need for adapted varieties of native species such as Idaho fescue (Festuca Idahoensis Elmer). Their usefulness, however, will be determined by their ability to produce seed, as well as maintain a productive stand (Borman et al. 1991).

Idaho fescue and cheatgrass are important components of many sagebrush steppe communities. Idaho fescue is a cool-season perennial bunchgrass indigenous to a variety of environments and plant communities in the Intermountain West (Eckert 1957, Hironaka et al. 1983, Doescher et al. 1986). It is also an excellent forage for wildlife and livestock (Stubbendieck et al. 1986, Vavra and Sneva 1978). Cheatgrass is an introduced annual grass that invaded and now dominates millions of hectares of the Intermountain West (Young et al. 1987 and Mack 1981). Attempts to establish native perennial grass species into stands of cheatgrass have met with limited success. Numerous studies have documented the aggressive and competitive nature of cheatgrass (Harris 1967, Young et al. 1987, Melgoza and Nowak 1991, Johnson and Aguirre 1991).

In spite of the apparent competitive advantage that cheatgrass has over native perennial bunchgrasses, some individual Idaho fescue plants persist with heavy grazing and high densities of cheatgrass in central Oregon. These remnant Idaho fescue populations may tolerate competition from cheatgrass better than plants growing on pristine areas. We hypothesized that, plants from remnant populations of Idaho fescue would be less impacted and more effective competitors when competing against cheatgrass than plants from pristine areas. The experiment compared aboveground growth of 4 collections of Idaho fescue from degraded sites to Idaho fescue from a pristine population under 3 cheatgrass planting densities and 2 watering regimes.

\section{Materials and Methods}

Idaho fescue seeds were collected in 1989 from 5 locations in central Oregon: (1) Island, (2) Lone Pine, (3) McCoin Orchard, (4) Blanchard Well, and (5) Combs Flat (Nasri 1993). Cheatgrass seeds were collected from only Combs Flat, because this species shows a lack of genetic diversity among populations (Novak et al. 1991). All sites, except the Island (Driscoll 1964), were currently being grazed by livestock, and we assumed have been grazed for 
Table 1. Significance levels for sources of variation and plant characteristics in split-hlock ANOVA for 5 Idaho fescue collections.

\begin{tabular}{|c|c|c|c|c|c|}
\hline $\begin{array}{l}\text { Source of } \\
\text { variation }\end{array}$ & $\mathrm{df}$ & $\begin{array}{c}\text { Shoot } \\
\text { biomass }\end{array}$ & $\begin{array}{l}\text { Shoot } \\
\text { height }\end{array}$ & $\begin{array}{c}\text { Tiller } \\
\text { number }\end{array}$ & $\begin{array}{c}\text { Leaf } \\
\text { number }\end{array}$ \\
\hline Block (B) & 3 & $\Rightarrow$ & NS & * & NS \\
\hline Water (W) & 1 & NS & NS & NS & NS \\
\hline Error (E) & 3 & & & & \\
\hline Density (D) & 2 & $*$ & $\neq$ & * & 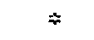 \\
\hline Error $B$ & 6 & & & & \\
\hline$W \times D$ & 2 & $*$ & NS & NS & NS \\
\hline Eттог C & 6 & & & & \\
\hline Collec. (C) & 4 & 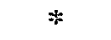 & $*$ & NS & NS \\
\hline $\mathrm{W} \times \mathrm{C}$ & 4 & NS & NS & NS & NS \\
\hline$C \times D$ & $\$$ & $*$ & $*$ & NS & NS \\
\hline$W \times C \times D$ & 8 & NS & NS & NS & NS \\
\hline Error & 72 & 0.011 & $\$ 13$ & 79 & 831 \\
\hline
\end{tabular}

F = Significunt at the 0.05 level of probubility. NS $=$ Nol significant at the 0.05 level of probability.

the last 125 years. These plant communities generally consisted of low densities of Idaho fescue, and high densities of cheatgrass (Goodwin 1993).

The competition experiment was conducted in the greenhouse during the fall of 1991 as a split-split block design with 4 blocks. Treatments consisted of 5 Idaho fescue collections, 3 cheatgrass densities $(0,5$, and 10$)$ and 2 watering regimes. Watering regime was the main plot, density the subplot, and collection the subsubplot (Little and Hills 1978). There were 2 replicates of each tratment combination.

Idaho fescue was initially grown from seed in the greenhouse for about 60 days, and then 2 plants were transplanted into each por (15-cm diameter $\times 18-\mathrm{cm}$ length) on 17 September 1991. Soil used in the experiment was collected on 19 June 1991 from Combs Flat, and was classified as a mixed, mesic Lithic Haploxeroll (Vaithus 1986). Only the surface $10 \mathrm{~cm}$ of soil was collected, and this was a very stony loam texture (Goodwin 1993). Each pot contained soil watered to field capacity. Established Idaho fescue plants were chosen for study to remove the potential effect that differences in seed mass have on subsequent seedling size and vigor (Zhang and Maun 1993), and to insure live seedlings were present for the experiment. After 7 days, Idaho fescue plants were thinned to 1 per pot and watered every 7 days. On 2 October 1991, cheatgrass density was ran- domly assigned to pots in an additive design (Harper 1977) at 3 ratios 1:0, 1:5, and 1:10. Cheatgrass was pregerminated in petri dishes and upon emergence of the radicle, placed so that the distance between a central Idaho fescue and cheatgrass seedling was constant at $5 \mathrm{~cm}$.

Two watering regimes were obtained after sowing of cheatgrass seeds by watering to field capacity once every 7 days or once every 14 days. The amount of water required to bring each pot to field capacity was estimated by measurements of wet and oven-dry weights on 6 pots randomly selected from each block, which represented the 2 watering regimes and 3 densities. The mean daily temperature in the greenhouse varied from 18 to $24^{\circ} \mathrm{C}$.

Idaho fescue and cheatgrass plants were allowed to establish in the pots for 35 days and 20 days, respectively. Beginning 22 October 1991 (Day 1), shoot height, tiller and leaf number were recorded at 7-day intervals. On day 56, Idaho fescue and cheatgrass plants were clipped at ground level (leaves and stems combined), oven-dried for 2 days at $80^{\circ} \mathrm{C}$, and weighed.

Shoot height, tiller and leaf number were evaluated using a repeated measures analysis of variance using the Statistical Analysis Systems (SAS Institute Inc. 1987) program. Shoot biomass was analyzed using analysis of variance. Upon detection of a significant $F$ value, mean separation involved both planned comparisons and the F-protected least significant difference (Steel and Torrie 1980). Planned comparisons were used to address a priori questions suggested by the original hypothesis: 1) does Idaho fescue from degraded sites tolerate competition better than Idaho fescue from the pristine site, and 2) does cheatgrass growth differ as a result of interference from collections of Idaho fescue. Least significant difference was used for comparison of different cheatgrass densities within an Idaho fescue collection (Thomas pers. comm.). Main effects and interactions were considered to be significant if $P \leq 0.05$; only significant differences are reported in the text.

\section{Results}

A significant 2-way (collection-by-density) interaction was observed for shoot biomass. At the end of 56 days, Idaho fescue collections growing in competition with cheatgrass at the $1: 5$ and

Table 2. Stoot biomass of Idaho fescue and cheatgrass at planting ratios of 1:0, 1:5, and 1:10 after 56 days. Values for Idaho fescue and cheatgrass are expressed as average weight per plant.

\begin{tabular}{|c|c|c|c|c|c|c|}
\hline & $\begin{array}{c}\text { Planting Ratio } \\
\text { Idaho } \\
\text { Fescue:Cheatgrass }\end{array}$ & \multicolumn{5}{|c|}{ Collections } \\
\hline \multirow[t]{3}{*}{ Idaho Fescue } & & $\ldots$ & $-\ldots$ & $-(g)$ & - . . . . . & $\ldots$ \\
\hline & $\begin{array}{l}1: 0 \\
1: 5\end{array}$ & $\begin{array}{l}0.57 \mathrm{~A}^{1} \mathrm{a}^{2} \\
0.37 \mathrm{Ba}\end{array}$ & $\begin{array}{l}0.33 \mathrm{Ab} \\
0.36 \mathrm{Aa}\end{array}$ & $\begin{array}{l}0.27 \mathrm{ABb} \\
0.36 \mathrm{Aa}\end{array}$ & $\begin{array}{l}0.29 \mathrm{ABb} \\
0.34 \mathrm{Aa}\end{array}$ & $\begin{array}{l}0.33 \mathrm{Ab} \\
0.34 \mathrm{Aa}\end{array}$ \\
\hline & $1: 10$ & $0.25 \mathrm{Ca}$ & $0.22 \mathrm{Ba}$ & $0.21 \mathrm{Ba}$ & $0.21 \mathrm{Ba}$ & $0.20 \mathrm{Ba}$ \\
\hline & $1: 5$ & $0.39 \mathrm{Aa}$ & $0.38 \mathrm{Aa}$ & $0.40 \mathrm{Aa}$ & $0.36 \mathrm{Aa}$ & $0.35 \mathrm{Aa}$ \\
\hline & $1: 10$ & $0.25 \mathrm{Ba}$ & $0.22 \mathrm{Ba}$ & $0.21 \mathrm{Ba}$ & $0.21 \mathrm{Ba}$ & $0.20 \mathrm{Ba}$ \\
\hline
\end{tabular}

\footnotetext{
1 Means followed by the same capital letter within a column are not signifieantly different $(P \leq 0.05)$ level.
}

2 Means followed by the scme lower case letter within a row are not significantly different $(P \leq 0.05)$ level. 
Tab*e 3. Shoat bicmass of Idaho fescue grown at 1:0, 1:5, and 1:10 planting ratios (Idaho fescue: cheatgrass) at 2 watering regimes at the end of 56 days.

\begin{tabular}{ccc}
\hline & \multicolumn{2}{c}{ Watering Regimes } \\
\cline { 2 - 3 } $\begin{array}{c}\text { Plant Ratio } \\
\text { Iduho Fescue: Chettgrass }\end{array}$ & 1 Week & 2 Weels \\
\hline & $0.32 \mathrm{Ala}^{1}$ & $0.39 \mathrm{Ab}$ \\
$1: 0$ & $0.41 \mathrm{Ba}$ & $0.30 \mathrm{Bb}$ \\
$1: 5$ & $0.25 \mathrm{Ca}$ & $0.18 \mathrm{Cb}$ \\
$1: 10$ & &
\end{tabular}

Means followed by the same capital letter within a column are not significantly different $(P \leq 0.05)$ level.

2 Menss followed by the same low er case letter within a row are not significantly different $(P \leq 0.05)$ level.

1:10 ratios did not differ in shoot biomass (Table 2). However, without cheatgrass (1:0), the Island collection produced a greater shoot biomass than the other Idaho fescue collections. Shoot biomass of the Island collection was reduced $35 \%$ at the $1: 5$ and $56 \%$ at the 1:10 ratios compared with the 1:0 control. Collections from the degraded sites had less shoot biomass than the control (1:0) only at the 1:10 ratio. No significant differences were observed in shoot biomass of cheatgrass plants to competition from Idaho fescue (Table 2). Mean shoot biomass of cheatgrass plants was greater in the 1:5 than the 1:10 ratio. However, total shoot biomass of cheatgrass was greatest at the 1:10 ratio.

A significant 2-way (watering-by-density) interaction was found for Idaho fescue shoot biomass. Idaho fescue grown without cheatgrass produced greater shoot biomass when watered once every 14 days than when watered once every 7 days (Table 3 ). In competition with cheatgrass, Idaho fescue produced the largest shoot biomass when watered once every 7 days. Shoot biomass was greater at the 1:5 ratio than at either the 1:0 and 1:10 ratios when watered every 7 days. Shoot biomass of Idaho fescue was less at 1:5 and 1:10 than 1:0 when watered every 14 days.

A significant 2-way (collection-by-density) interaction was found for shoot height (Table 4). Shoot height of Idaho fescue was generally shortest at $1: 0$ and tallest at the $1: 5$ or $1: 10$ ratios (Table 4). At the 1:0 and 1:10 ratios, shoots of the Island collection were tallest. No differences were found among collections at the 1:5 ratio. Shoot height of cheatgrass was generally shortest at the 1:10 ratio (Table 4). No differences were observed in shoot height of cheatgrass in response to competition from the Idaho fescue collections (data not shown).

Idaho fescue collections did not differ from one another at any level of cheatgrass competition in tiller production (data not shown). Tiller numbers of Idaho fescue seedlings at 56 days differed between competition levels, and averaged 38, 9, and 6 for the 1:0, 1:5, and 1:10 ratios, respectively. Cheatgrass plants produced 1 to 5 tillers during the 56 day trial, but no clear pattern evolved from the competition ratios.

Leaf number per plant increased for both cheatgrass and Idaho fescue (data not shown). Idaho fescue plants produced more leaves than cheatgrass, but leaf numbers were similar among collections. At the end of 56 days, leaf numbers of Idaho fescue plants declined with increasing competition, and averaged 109 for the $1: 0$ ratio, 34 for the $1: 5$ ratio, and 22 for the $1: 10$ ratio. Cheatgrass produced more leaves at the 1:5 (24) than the 1:10 ratio (17).

\section{Discussion}

Results of this research show that response of Idaho fescue progeny to competition from cheatgrass varies depending on whether parent plants are growing on degraded sites with a high occupancy of cheatgrass or on pristine sites with a low occupancy of cheatgrass. When grown without cheatgrass competition, seedlings of plants from degraded sites were lighter and shorter than seedlings from the pristine plants, but produced similar numbers of tillers. These findings are consistent with the research by Jaindl et al. (1994) that found collections grown in common garden conditions exhibited similar growth morphologies. When grown in competition with cheatgrass, all collections responded similarly, although only aboveground biomass of the pristine population declined from the 1:0 to the 1:5 ratio. These findings suggest plants from the degraded and pristine sites tolerate a limited amount of competition from cheatgrass, but that total shoot biomass would be greatest for plants collected from the pristine site without cheatgrass competition.

The greater shoot biomass produced by Idaho fescue seedlings from the pristine area compared with seedlings from the degraded areas indicates that the Island collection exhibits genetic plasticity. Seedlings from the pristine population produced greater aboveground biomass without competition, whereas plants evolving with competition and herbivory did not respond. These differences between collections are consistent with the concept of ecotypic differentiation (Turreson 1922). The findings are also consistent with observations that a history of frequent and intense defoliation often selects for shorter and more prostrate genotypes (Etherington 1984; Coppock et al. 1983, Carman 1985, Polley and Detling 1988).

Table 4. Shoot heights of Idaho fescue and cheatgrass at 1:0, 1:5, and 1:10 planting ratios (Idaho fescue: cheatgrass at the end of 56 days).

\begin{tabular}{|c|c|c|c|c|c|c|}
\hline \multirow[b]{2}{*}{ Spacies } & \multirow[b]{2}{*}{$\begin{array}{l}\text { Plenting Ratio: Idaho } \\
\text { Fescue:Cheatgrass }\end{array}$} & \multicolumn{5}{|c|}{ Idaho fescue collections } \\
\hline & & Island & $\begin{array}{l}\text { Blanchard } \\
\text { Well }\end{array}$ & Combs Flat & Lone Pine & $\begin{array}{c}\text { MCC } \\
\text { Orchard }\end{array}$ \\
\hline IJaho Fescue & & $\cdots$ & & $(\mathrm{mm})-$ & -- & $-\ldots$ \\
\hline & $\begin{array}{l}1: 0 \\
1: 5 \\
I: 10\end{array}$ & $\begin{array}{l}276 \mathrm{~A}^{1} \mathrm{a}^{2} \\
322 \mathrm{Ba} \\
302 \mathrm{ABa}\end{array}$ & $\begin{array}{l}191 \mathrm{Ab} \\
319 \mathrm{Ba} \\
291 \mathrm{Bb}\end{array}$ & $\begin{array}{l}191 \mathrm{Ab} \\
323 \mathrm{Ba} \\
291 \mathrm{Cb}\end{array}$ & $\begin{array}{l}183 \mathrm{Ab} \\
312 \mathrm{Ba} \\
278 \mathrm{Cb}\end{array}$ & $\begin{array}{l}190 \mathrm{Ab} \\
308 \mathrm{Ba} \\
283 \mathrm{Bb}\end{array}$ \\
\hline
\end{tabular}

Means followed by the same capital letter within a column are not significantly different $(P \leq 0.05)$ level.

2 Means followed by the same lower case letter within a row are not significantly different $(P \leq 0.05)$ level. 
In conclusion, this study and several other studies performed on these Idaho fescue collections (Goodwin 1993, Jaindl et al. 1994), suggests ecotypic differentiation has occurred in central Oregon populations of Idaho fescuc. Persistence of Idaho fescue on degraded sites in central Oregon may be partially explained by their ability to tolerate moderate levels of cheatgrass competition and their shorter growth form. Further testing would be required to determine their potential as plant materials for revegetating degraded range sites in the Northern Great Basin.

\section{Literature Cited}

Borman, M. M., W. C. Krueger, and D. E. Johnson. 1991. Effects of establishment perennial grasses on yields of associated weeds. J. Range Mianage. 44:318-322.

Carman, J. G. 1985. Morphological characterization and defoliation responses of selected Shizachyrium scoparium genotypes. Amer. Midl. Natur. 11 $4: 37-43$.

Coppock, D. L., J. K. Detling, J. E. Ellis, and M. I. Dyer. 1983. Plantherbivore interactions in a North America mixed-grass prairie. I. Effects of black-tailed prairie dogs on intraseasonal aboveground plant biomass and nutrient dynamics and plant species diversity. Oecologia 56:10-15.

Djescher, P. S., R. F. MTiller, S. R., Swanson, and A. H. Winward. 1986. Identification of the Aremisia tridentata ssp. Wyomingensis/Festuca idahoensis habitat type in Eastern Oregon. Northwest Sci. 60:55-60.

Driscoll, R. S. 1964. A relict area in the central Oregon juniper zone. Ecol. 45:345-353.

Eckert, R. E. Jr. 1957. Vegetation-soil relationships in some Artemisia types in Norhern Hamey and Lake Counties, Oregon. Ph.D. Diss. Oregon State University. Corvallis, Ore.

Etherington, J. E. 1984. Relationship between morphological adaptation to grazing. carbon balance and waterlogging tolerance in clones of Dactilis glomerata L. New Phyrol. 98:647-658.

Evans, R. A., and J. Young. 1970. Plant litter and establishment of alien annual weed species in rangeland communities. Weed Sci. 18:697-703.

Goodwin, J. R. 1993. Ecotypic variation, adaptation, and persistence of Idoho fescue on degraded central Oregon rangelands, M. S. thesis. Oregon State University. Corvallis, Ore.

Harper, J. L. 1977. Population biology of plants. Academic Press. N.Y.

Herris, G. A. 1967. Some competitive relationships between Agropyron spicanm and Bromus tectorum. Ecol. Monogr. 37:89-111.

Fironaka, M., M. A. Fosberg, and A. H. Winward. 1983. Sagebrushgrass habitat types of southern Idaho. Bull. No. 35. College of Forestry, Wildlife and Range Sciences. Univ. of Idaho. Moscow, Ida.

Jainall, R. G., P. S. Duescher, R. F. Miller, and L. E. Eddleman. 1994. Persistence of Idaho fescue on degraded rangelands: Adaptation to defoliction or tolerance. J. Range Manage. 46:54-59.

Johnson, D. A., and L. Aguirre. 1991. Effect of water on morphological development in seedlings of three range grasses: Root branching pattern. J. Range Manage. 44:355-360.

Jordan, W. R. II, M. E. Gilpin, and J. D. Aber. 1987. Restoration ecology research. Cimbridge Univ. Press, Cambridge.

Little, T. M., and F. G. Hills. 1978. Agricultural experimentation. John Wiley and Sons. N.Y.

Mack, R. N. 1981. Invasion of Bromus tectorum L. into western North America: An ecological chronicle. Agro-ecosystems 7:145-165.

Melgoza, G., and R. S. Nowak. 1991. Competition between cheatgrass and two native species after fire. Implications for observations and measurements of root distributions. J Range Manage 44:27-32.

Nasri, M. 1993. Effect of temperature and competition on shoot and root growth of cheatgrass (Bromus tectorum L.) and 5 collections of Idaho fescue (Festuca idahoensis Elmer). MS. Thesis. Oregon State Universiry: Corvallis, Ore.

Norak, S. J. , R. N. Mack, and D. E. Solstis. 1991. Genetic variation in Bromus fectorun (Poaceae): population differentiation in its North American range. Am. J. Bot. 78:1 150-1161.
Polley H. W., and J. K. Detling. 1988. Herbivory tolerance of Agropyron smithii populations with different grazing histories. Oecologia 77:261-267.

SAS Institute Inc. 1987. SAS/STAT Guide for personal computers, version 6 ed., Cary, N.C.

Sheridon, D. 1981. Desertification in the United States. Council on environmental quality. Washington, DC.

Steel, R. G. D., and J. H. Torrie. 1980. Principles and procedures of statistics, second edition. McGraw-Hill Book Company Inc. N.Y.

Stubbendieck, J., S. L. Hatch, and C. H. Butterfield. 1992. North American range plants, fourth edition. University of Nebraska Press. Lincoln, Nebr.

Turreson, G. 1922. The species and the variety as ecological units. Hereditas 3:100-113.

Vavra, M., and F. Sneva. 1978. Seasonal diets of five ungulates grazing the cold desert biome, 435-437. In: Hyder, D. (ed.). Proceedings of the First International Rangeland Congress. Soc. Range Manage. Denver, Colo.

Vaitkus, M. R. 1986. Effect of western juniper on understory herbage production in central Oregon. M. S. Thesis. Oregon State University. Corvallis, Ore.

Young, J. A., R. A. Evans, R. E. Eckert Jr., and B. L Kay. 1987. Cheatgrass. Rangelands 9:266-270.

Zhang, J., and M. A. Maun. 1993. Components of seed mass and their relationship to seedling size in Calamovilfa longifolia. Can. J. Bot. 71:551-557. 